\title{
Bifidobacterium magnum sp. nov., a Large, Acidophilic Bifidobacterium Isolated From Rabbit Feces
}

\author{
V. SCARDOVI and G. ZANI
}

Istituto di Microbiologia Agraria, Università di Bologna, Bologna, Italy

\begin{abstract}
Among 130 strains of bifidobacteria isolated from the feces of rabbits, 26 were distinctive in: (i) having large cellular dimensions ( 4 to 5 by 17 to $20 \mu \mathrm{m}$ ); (ii) requiring an initial $\mathrm{pH}$ of 5.3 to 5.5 for optimum growth; and (iii) having a need for Tween 80 for optimal development in Trypticase-phytone-yeast extract-glucose medium. The other characters of these 26 strains, such as their temperature and oxygen relationships, catalase production, nitrate reduction, end products from glucose fermentation, enzymes of the hexose catabolic pathway, the percent of guanine plus cytosine in the deoxyribonucleic acid (DNA), etc., are similar to those of most bifidobacteria. However, DNA-DNA hybridization studies revealed little or no polynucleotide sequence similarity to any other members of the genus Bifidobacterium. We therefore regard these 26 strains as constituting a new species, for which we propose the name Bifidobacterium magnum. The type strain of this new species is RA3 (= ATCC 27540).
\end{abstract}

Bifidobacterium animalis (Mitsuoka) Scardovi and Trovatelli (9) was isolated from the feces of rabbits, rats, and chickens. However, the feces of rabbits commonly harbor other bifidobacteria whose phenotypic characters have not been described in detail and whose taxonomic status is therefore unclear. Because of the extremely large dimensions of their cells and aggregates, such strains were at first not considered to be bifidobacteria. However, the production by these strains of fructose-6-phosphate phosphoketolase (F6PPK), the key enzyme of the glucose catabolic pathway in the genus Bifidobacterium $(2,8)$, and of acetic and lactic acids as chief end products of glucose metabolism in the usual ratios 2 to $3: 1$, indicates that these strains can be considered to be members of the genus Bifidobacterium.

In this investigation, these bifidobacteria are described and named, a type strain is designated, and their deoxyribonucleic acid (DNA) homology relationships with other known species of bifidobacteria are reported.

\section{MATERIALS AND METHODS}

Bacterial strains. The strains employed and their sources are listed in Table 1. The type strains of the known species of Bifidobacterium listed in Table 1 have been used previously for DNA-DNA hybridization studies $(6,9)$. In addition, six isolates from sewage (F182, F184, F232, F281, F414, and F508), identified as $B$. longum Reuter on DNA relatedness and phenotypic characters (our unpublished data), were used in this study as additional competitors in DNA-DNA hybridizations.

Isolation and cultivation of strains. Bifidobacteria were isolated from rabbit feces by means of the usual anaerobic platings on Trypticase-phytone-yeast extract (TPY) medium (10). Although this medium was used with satisfactory results throughout our previous investigations on bifidobacteria, it was nevertheless unsuitable for good growth of these 26 new bifidobacteria from rabbits: colonies were slow-growing and minute, and growth in stabs and broth was rather scant. These organisms grew more rapidly and abundantly in MRS medium (1). In a preliminary survey on the effects of various additives to the basic TPY medium, it was found that Tween $80(1 \mathrm{~g} / \mathrm{liter})$ enhanced growth. Subsequently, therefore, MRS and Tween 80 enriched TPY media at a $\mathrm{pH}$ value of 6.0 were used (see below).

DNA-DNA hybridization. All the procedures involved, from cell lysis to counting filter-fixed ${ }^{1}{ }^{4} \mathrm{C}$-DNA, have been previously described $(10)$. The only modification of the published methods adopted in this study was that cells for DNA extraction were grown in MRS instead of TPY medium. However, labeling of DNA with the usual amounts of $50 \mu \mathrm{Ci}$ each of uracil-2 $-{ }^{1}{ }^{4} \mathrm{C}$ and adenine $-8 .{ }^{14} \mathrm{C}$ per liter was almost nil in MRS medium (some 120 counts per min per $\mu \mathrm{g}$ ). Therefore, the cells were cultivated in TPY medium seeded with large inocula $(10 \% \mathrm{vol} / \mathrm{vol})$ from cells previously grown in MRS medium (DNA activity, 700 counts per min per $\mu \mathrm{g}$ ).

Assessment of physiological and biochemical characters. The methods used were previously de- 
TABLE 1. Strains used

\begin{tabular}{|c|c|c|}
\hline Organisms & Isolated from & $\begin{array}{l}\text { Culture received } \\
\text { from }\end{array}$ \\
\hline Bifidobacterium magnum sp. nov. & & \\
\hline $\begin{array}{l}\text { RA3 (Type strain) }(=\text { ATCC } 27540) \text {; RA1; RA4; RA5; RA6; RA8; RA9 } \\
\text { RA10; RA11; RA76; RA77; RA78; RA89; RA184; RA185; RA189; }\end{array}$ & Feces of rabbit & Our collection \\
\hline 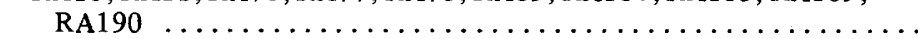 & Feces of rabbit & Our collection \\
\hline RA $203 ;$ RA $206 ;$ RA209; RA $220 ;$ RA221; RA $222 ;$ RA $223 ;$ RA225 & Feces of rabbit & Our collection \\
\hline B. bifidum (Tissier) Orla-Jensen S28a (=ATCC 15696) $\ldots \ldots \ldots \ldots$ & Feces of infant & G. Reuter \\
\hline B. breve Reuter S1 (=ATCC 15700) Type strain (5) & Feces of infant & G. Reuter \\
\hline B. liberorum Reuter S76e (=ATCC 15702) Type strain (5) & Feces of infant & G. Reuter \\
\hline B. adolescentis Reuter E298b (=ATCC 15705) (5) .... & Feces of adult & G. Reuter \\
\hline $\begin{array}{l}\text { B. longum Reuter E194b (=ATCC 15707) Type strain (5) ..... } \\
\text { B. catenulatum Scardovi and Crociani B669 (=ATCC 27539) Type }\end{array}$ & Feces of adult & G. Reuter \\
\hline $\begin{array}{l}\text { B. catenulat um Scardovi and Crocianı B669 }(=\mathrm{ATCC} 27539) \text { Туре } \\
\text { strain (6) } \ldots \ldots \ldots \ldots \ldots \ldots \ldots \ldots \ldots \ldots \ldots \ldots \ldots\end{array}$ & Feces of adult & Our collection \\
\hline B. angulatum Scardovi and Crociani B677 (=ATCC 27535) Type & & \\
\hline $\begin{array}{l}\text { strain }(6) \ldots \ldots \ldots \ldots \ldots \ldots \ldots \ldots \ldots \ldots \ldots \\
\text { B. dentium Scardovi and Crociani B764 (=ATCC } 27534) \text { Type }\end{array}$ & Feces of adult & Our collection \\
\hline strain $(6) \ldots \ldots \ldots \ldots \ldots \ldots \ldots \ldots \ldots$ & Dental caries & Our collection \\
\hline B. globosum Scardovi et al. RU230 (=ATCC 25864) Type strain & Rumen of cattle & Our collection \\
\hline $\begin{array}{l}\text { B. ruminale Scardovi et al. RU326 (=ATCC 25866) Type strain . } \\
\text { B. animalis (Mitsuoka) Scardovi and Trovatelli P23 (=ATCC }\end{array}$ & Rumen of cattle & Our collection \\
\hline 27536$)(9) \ldots \ldots \ldots \ldots \ldots \ldots \ldots \ldots \ldots \ldots$ & Feces of chicken & Our collection \\
\hline B. suis Matteuzzi et al. SU859 (=ATCC 27533) Type strain (3) & Feces of pig & Our collection \\
\hline minimum group F392 (=ATCC 27538) reference strain (9) & Sewage & Our collection \\
\hline subtile group F395 (=ATCC 27537 ) reference strain (9). & Sewage & Our collection \\
\hline B. longum Reuter F182; F184; F232; F281; F414; F508 & Sewage & Our collection \\
\hline
\end{tabular}

scribed $(6,10)$. Tween 80 -enriched TPY medium was used as the basal medium.

\section{RESULTS}

DNA homology relationships. The DNA relatedness of the new isolates to known species of bifidobacteria was ascertained using strain RA 3 as reference and DNA competitors from strains RA1, RA76, RA89, RA203, and RA206. Because of the extreme phenotypic uniformity of the group, the DNA competition experiments were confined to these five strains. The data in Table 2 show the high DNA relatedness of the DNA competitors of the new isolates to the RA3 reference system and the low or zero levels of homology displayed by all other competitor DNAs tested; the latter represented all species of Bifidobacterium except for $B$. asteroides, $B$. indicum, and $B$. coryneforme, species found in the intestines of bees.

The DNA of the type strain of B. longum, E194b (= ATCC 15707), was used in homology and competition studies with DNA from reference strain RA3 of the new isolates (Tables 2, 3 ). There was no homology or competition between the two DNA preparations. Early in this study, we observed some similarity be-
TABLE 2. DNA relatedness of $B$. magnum and other species of Bifidobacterium to B. magnum RA3 used as reference

\begin{tabular}{|c|c|}
\hline Competitor strains & $\begin{array}{l}\text { Reference strain } \\
\text { B. magnum RA3 }\end{array}$ \\
\hline \multicolumn{2}{|l|}{ Bifidobacterium magnum sp. nov. } \\
\hline RA3 (Type strain) $\ldots \ldots \ldots \ldots \ldots$ & 100 \\
\hline RA1; RA76 & $106-75$ \\
\hline RA $89 ;$ RA203; RA206 & $79-106-77$ \\
\hline 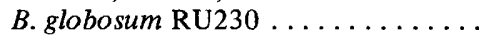 & 32 \\
\hline B. ruminale RU326 $\ldots \ldots \ldots$ & 11 \\
\hline B. animalis $\mathrm{P} 23 \ldots \ldots \ldots \ldots \ldots \ldots$ & 15 \\
\hline B. suis SU859 & 10 \\
\hline B. bifidum $\mathrm{S} 28 \mathrm{a}$ & 5 \\
\hline B. breve $\mathrm{S} 1 \ldots$ & 10 \\
\hline B. liberorum $\mathrm{S} 76 \mathrm{e}$ & 15 \\
\hline B. adolescentis $\mathrm{E} 298 \mathrm{~b}$ & 14 \\
\hline B. longum E194b... & 00 \\
\hline F182;F184;F232 (from sewage) ${ }^{a}$ & $16-29-10$ \\
\hline F281; F414; F508 (from sewage) ${ }^{\alpha}$ & $3-00-20$ \\
\hline 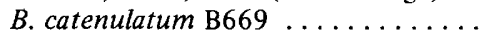 & 17 \\
\hline B. angulatum $\mathrm{B} 677 \ldots$ & 5 \\
\hline B. dentium $\mathrm{B} 764$. & 8 \\
\hline minimum group $\mathrm{F} 392$. & 19 \\
\hline subtile group F395 ... & 00 \\
\hline
\end{tabular}

${ }^{a}$ These strains, genetically $B$. longum, were used as additional competitors. Their homologies to reference B. longum E194b ( $=\mathrm{ATCC} 15707$ ) were: $\mathrm{F} 182=100$; F184=95; F232 $=80 ; \quad F 281=93 ; \quad F 414=81 ; \quad$ and F508=100 (our unpublished data). 
TABLE 3. DNA relatedness of B. magnum $R A 3$ (used as competitor) to type strains of species of the genus Bifidobacterium (used as references)

\begin{tabular}{|c|c|}
\hline Reference strains & $\begin{array}{c}\text { Competitor DNA } \\
\text { from } B . \text { magnum } \\
\text { RA3 }\end{array}$ \\
\hline B. magnum RA3 & 100 \\
\hline B. globosum RU230 & 6 \\
\hline B. ruminale RU326 . . . . . . . & 20 \\
\hline B. animalis $\mathrm{P} 23 \ldots$ & 23 \\
\hline B. suis SU859. & 9 \\
\hline B. bifidum $\mathrm{S} 28 \mathrm{a} \ldots$ & 10 \\
\hline B. breve $\mathrm{S} 1 \ldots \ldots \ldots \ldots \ldots$ & 9 \\
\hline B. liberorum $\mathrm{S} 76 \mathrm{e} \ldots \ldots \ldots \ldots$ & 17 \\
\hline B. adolescentis E298b . . . . . . . . & 6 \\
\hline 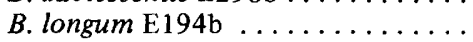 & 4 \\
\hline B. catenulatum $\mathrm{B} 669$.. & 26 \\
\hline B. angulatum $\mathrm{B} 677 \ldots \ldots \ldots \ldots$ & 5 \\
\hline B. dentium B764 $\ldots \ldots \ldots \ldots \ldots$ & 21 \\
\hline minimum group $\mathrm{F} 392 \ldots$ & 20 \\
\hline subtile group F395 ...... & 7 \\
\hline
\end{tabular}

tween certain strains of $B$. longum and the rabbit isolates in sugar fermentation patterns and enlarged cell sizes (under unusual growth conditions of $B$. longum). Consequently, we investigated the genetic relatedness of six additional strains of $B$. longum to the reference strain RA3 of the group of new isolates (Table 2 ); the range of homology values ( 0 to $29 \%$, with a mean value of $13 \%$ ) suggests that an insignificant number of nucleotide sequences are shared by the two groups.

The order of magnitude of DNA homology levels between the new strains and those of the known species of Bifidobacterium was confirmed in reverse competition reactions, i.e., by the use of DNA from strain RA3 as competitor in 14 reference systems (Table 3). Except for $B$. globosum RU230, $B$. ruminale RU326, and $B$. dentium $\mathrm{B} 764$, the correspondence between the two sets of values ( 0 to $32 \%$ in Table 2 , and 4 to $26 \%$ in Table 3 ) are rather good. At these low levels of similarity, more replicate analyses might improve the already generally good comparability shown in Tables 2 and 3.

Morphology. The outstanding character of the new isolates is the size of the cellular elements and of the aggregates (Plate 1). Elements $20 \mu \mathrm{m}$ long are frequent either as isolated cells or as aggregates; cells are thick (0.6 to $2.0 \mu \mathrm{m})$, sometimes constricted to round fragments in chains (Fig. 3 of Plate 1). In broth cultures, cells are generally shorter. In strain RA76 (Fig. 6 of Plate 1), cells are curiously spindle shaped with apparently flexuous contours. The difference in size between cells of the new isolates and those of the "minimum" group of bifidobacteria is dramatic (Plate 2).

Fermentation pattern and other characters. The sugars fermented by the new species (see below) are those fermented by $B$. longum and $B$. suis. All the other characters studied are common to most bifidobacteria, except for the $\mathrm{pH}$ relationships. The strains of the new species develop rapidly at a $\mathrm{pH}$ considerably lower than the optimum $\mathrm{pH}$ of the bifidobacteria from the feces of animals or the rumen of cattle. $B$. bifidum is re;orted to have an optimum $\mathrm{pH}$ of 6.0 to 7.0 , and explicit data are not given for the other bifidobacteria found in human habitats, namely $B$. breve, $B$. adolescentis, and $B$. longum (4). The acidophilic property of the new strains is apparently unique among bifidobacteria.

Based on DNA homology relationships and several outstanding phenotypic characters as described below (mainly size of cells and acidophily), we propose that the new isolates be named Bifidobacterium magnum sp. nov. (L. adj. magnus large, great).

Bifidobacterium magnum sp. nov.

Cell characteristics. Long, thick, irregularly contoured rods measuring 2 by 10 to $20 \mu \mathrm{m}$ and occurring frequently in aggregates; long branches are common; some cells have tapered ends or are spindle shaped. Club-shaped or swollen rods are rare. Gram positive. Nonmotile. Endospores not produced (Plates 1 and 2).

Surface colonies (TPY medium). Circular, raised with somewhat elevated central area, whitish to gray, opaque and soft (Plate 1, Fig. 8 and 9).

Relationships to oxygen and $\mathbf{C O}_{2}$. Highly anaerobic; $\mathrm{CO}_{2}$ has no effect on oxygen sensitivity or anaerobic growth.

Temperature relationships. Optimum, 37.0 to 39.0 ; minimum, $28 \mathrm{C}$; maximum, 42.5 to 43.0 $\mathrm{C}$; does not grow at 26.0 or $44.5 \mathrm{C}$.

pH relationships. Initial optimum, 5.3 to 5.5 ; growth is retarded at 5.0 or 5.9 ; no growth (after two days) at 4.2 or 7.0.

End products from glucose. The lactic acid and acetic acid molar ratio is $1: 1.9 \pm 0.1$ in MRS medium. Produces $\mathbf{L}(+)$ lactic acid. Formic, propionic, and butyric acids are not produced.

Nutrition. Tween 80 is highly stimulatory.

Fermentation pattern. All strains ferment glucose, fructose, galactose, arabinose, xylose, ribose, sucrose, maltose, lactose, melibiose, and raffinose. Mannose, cellobiose, trehalose, melezitose, mannitol, sorbitol, starch, dextrin, inulin, salicin, and gluconate are not fermented. 

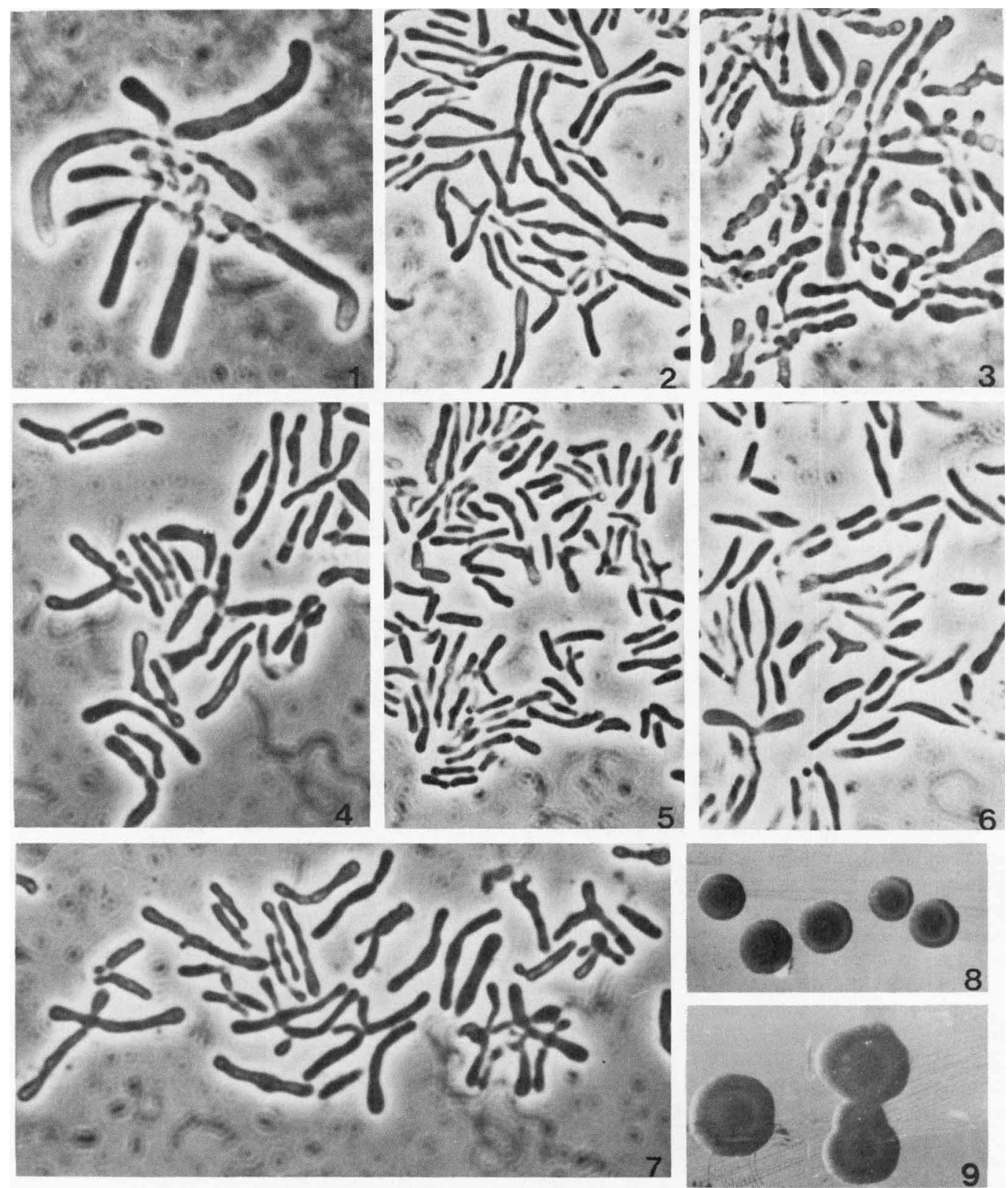

PLATE 1. Morphology of Bifidobacterium magnum sp. nov. Fig. 1. Cells of the type strain (RA3) from a fresh anaerobic stab in normal TPY medium shortly after isolation. Fig. 2 and 3. Cells of strains RA8 and RA10, respectively, as above. Fig. 4. Cells of strain RA233 from a fresh stab in MRS medium. Fig. 5. Cells of strain RA3 from liquid MRS medium (DNA extraction). Fig. 6. Cells of strain RA76, as above in Fig. 5. Fig. 7. Cells of strain RA276 from a 6-day-old MRS broth culture. Phase contrast. $\times 1,500$. Fig. 8 and 9 . Surface colonies of the type strain (RA3). $\times 10$. 

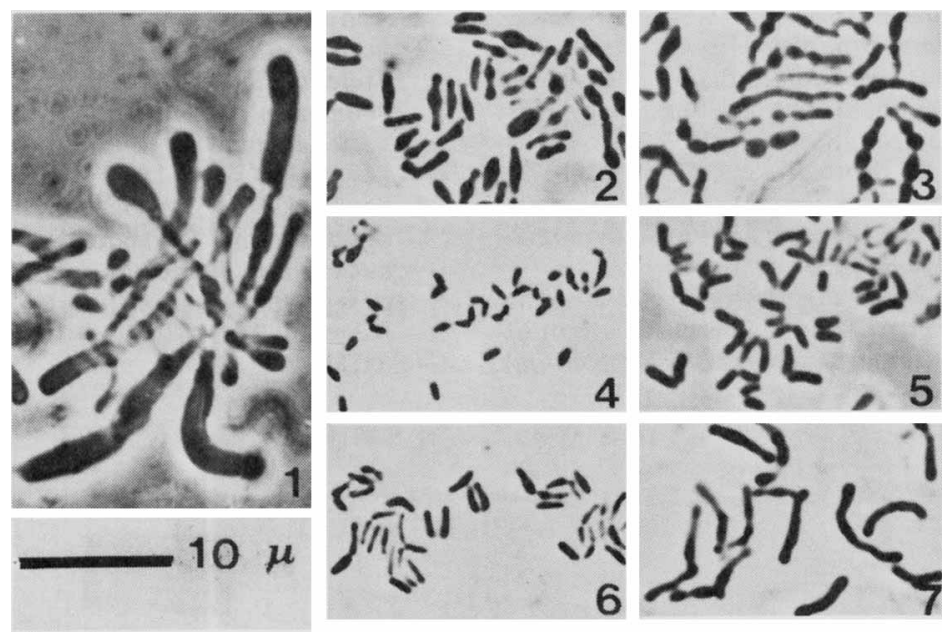

PLATE 2. Comparative morphology of B. magnum and other bifidobacteria. Fig. 1. Cells of the type strain (RA3) of B. magnum. Fig. 2. Cells of B. animalis strain P23. Fig. 3. Cells of the type strain (B669) of B. catenulatum. Fig. 4. Cells of strain F392 of the minimum group. Fig. 5. Cells of the type strain (B677) of B. angulatum. Fig. 6. Cells of strain F395 of the subtile group. Fig. 7. Cells of the type strain (B674) of B. dentium. Phase contrast. $\times 1,500$.

As with all other bifidobacteria, glycerol, rhamnose, and lactate are also not fermented.

B. longum Reuter and B. suis Metteuzzi et al. display the same fermentation pattern as $B$. magnum.

Enzymology. Fructose-1,6-diphosphate aldolase-some 4 to $5 \mathrm{mU}$ of specific activity are produced; glucose-6-phosphate dehydrogenase (oxidized nicotinamide adenine dinucleotide phosphate $\left[\mathrm{NADP}^{+}\right]$dependent) is demonstrable; 6-phosphogluconate dehydrogenase (NADP ${ }^{+}$dependent)-about $70 \mathrm{mU}$ of specific activity are produced; the electrophoretic type of F6PPK produced is the same as that of the species of bifidobacteria from animals (7).

Biochemical reactions. Catalase and pseudocatalase (hemin) are not produced. Nitrate not reduced. Indole and acetylmethylcarbinol are not produced. Gelatin is not liquefied. Skim milk is acidified and coagulated. Ammonia is not produced from urea or from arginine.

G + C content of DNA. $60.0 \pm 0.6 \mathrm{~mol} \%$ $\left(T_{m}\right)$.

DNA homology relationships. Practically unrelated to any other species (or groups) of the genus Bifidobacterium (homology ranging from 5 to $30 \%$ ).

Source. Feces of adult rabbits.

The type strain is RA3 from the Collection of the Istituto di Microbiologia Agraria, Università di Bologna, Bologna, Italy. It has been deposited in the American Type Culture Collection, Rockville, Md., as ATCC 27540.

\section{ACKNOWLEDGMENTS}

This investigation was supported by a research grant from the Consiglio Nazionale delle Ricerche, Roma. We are grateful for this financial support.

The technical assistance of N. Vincenzi is gratefully acknowledged.

\section{REPRINT REQUESTS}

Address reprint requests to: Dr. V. Scardovi, Istituto di Microbiologia Agraria, Università di Bologna, Bologna, Italy.

\section{LITERATURE CITED}

1. De Man, J. C., M. Rogosa, and M. E. Sharpe. 1960. A medium for the cultivation of lactobacilli. J. Appl. Bacteriol. 23:130-135.

2. de Vries, W., S. J. Gerbrandy, and A. H. Stouthamer. 1967. Carbohydrate metabolism in Bifidobacterium bifidum. Biochim. Biophys. Acta 136:415-425.

3. Matteuzzi, D., F. Crociani, G. Zani, and L. D. Trovatelli. 1971. Bifidobacterium suis n. sp.: a new species of the genus Bifidobacterium isolated from pig feces. Z. Allg. Mikrobiol. 11:387-395.

4. Reuter, G. 1963-64. Vergleichende Untersuchungen über die Bifidus-Flora im Sauglings- und Erwachsenenstuhl. Zentralbl. Bakteriol. Parasitenk. Infektionskr. Hyg. Abt. I Orig. 191:486-507.

5. Reuter, G. 1971. Designation of type strains for Bifidobacterium species. Int. J. Syst. Bacteriol. 21:273-275. 
6. Scardovi, V., and F. Crociani. 1974. Bifidobacterium catenulatum, Bifidobacterium dentium, and Bifidobacterium angulatum: three new species and their deoxyribonucleic acid homology relationships. Int. J. Syst. Bacteriol. 24:6-20.

7. Scardovi, V., B. Sgorbati, and G. Zani. 1971. Starch gel electrophoresis of fructose-6-phosphate phosphoketolase in the genus Bifidobacterium. J. Bacteriol. 106:1036-1039.

8. Scardovi, V., and L. D. Trovatelli. 1965. The fructose-6-phosphate shunt as peculiar pattern of hexose degradation in the genus Bifidobacterium.
Ann. Microbiol. 15:19-29.

9. Scardovi, V., and L. D. Trovatelli. 1974. Bifidobacterium animalis (Mitsuoka) comb. nov. and the "minimum" and "subtile" groups of new bifidobacteria found in sewage. Int. J. Syst. Bacteriol. 24:21-28.

10. Scardovi, V., L. D. Trovatelli, G. Zani, F. Crociani, and D. Matteuzzi. 1971. Deoxyribonucleic acid homology relationships among species of the genus Bififobacterium. Int. J. Syst. Bacteriol. 21:276-294. 